\title{
GILLNET SELECTIVITY TO ROACH, RUTILUS RUTILUS, FROM THE SZCZECIN LAGOON, POLAND
}

\author{
Iwona PSUTY*, Bohdan DRAGANIK, and Wiesław BLADY
}

\author{
Sea Fisheries Institute in Gdynia, Poland
}

Psuty I., Draganik B., Blady W. 2007. Gillnet selectivity to roach, Rutilus rutilus, from the Szczecin Lagoon, Poland. Acta Ichthyol. Piscat. 37 (1): 17-23.

\begin{abstract}
Background. Roach, Rutilus rutilus, comprise a large proportion of the total catch in the Szczecin Lagoon, and are caught mainly as bycatch in gillnets targeting perch, Perca fluviatilis. The minimum landing length for roach and perch is $17 \mathrm{~cm}$ TL and the minimum mesh size is $30 \mathrm{~mm}$ bar length. However, little is known about the selectivity of roach, which may have implications for implementing effective regulations. Consequently, the aims of the study were to estimate roach selectivity curves and to compare the results with perch selectivity.

Materials and Method. The study was based on the length frequency of catch from standardized fishing practice with commercial gillnets of mesh sizes ranging from 25 to $35 \mathrm{~mm}$ (bar length) and modelled using various generalized linear models. The best model was selected using deviance criteria.

Results. The log-normal selectivity model provided the best fit, with spread relevant to mesh size under the assumption of equal fishing power. The estimated parameters were $18.7 \mathrm{~cm}$ and 1.5 (mode and spread of selectivity curve for the smallest mesh size).

Conclusions. Although the most efficient mesh size for roach was $26 \mathrm{~mm}$, its use in the Szczecin Lagoon is limited by impact on perch. All the studied mesh sizes prevented catches of undersized roach, while mesh sizes from $28 \mathrm{~mm}$ prevented catches of undersized perch $(\mathrm{MLL}=17 \mathrm{~cm} \mathrm{TL})$. The authors concluded that the current $30 \mathrm{~mm}$ minimum mesh size is likely effective at preventing the harvest of undersized perch and roach.
\end{abstract}

Keywords: roach, gillnet, selectivity, log-linear modelling, SELECT method

\section{INTRODUCTION}

Gillnets are used widely in the Szczecin Lagoon fishery to catch pike-perch, Sander lucioperca (L.), common bream, Abramis brama (L.), European perch, Perca fluviatilis L., and roach, Rutilus rutilus (L.). Since the latter two species are of similar size, catches of them are made with the same fishing gear, namely gillnets. The gillnet fishery is directed predominantly at perch, with roach being bycatch. Consequently, the fishery effort and regulations directed at one of these species may affect the harvest of the other. This issue has become especially important since the 1990s, when, according to the authors' own observations, an increase in the price paid to fisherman for perch spurred a substantial increase in the gillnet fishing effort.

In the Szczecin Lagoon, the roach and perch minimum landing lengths are the same $(17 \mathrm{~cm} \mathrm{TL})$, and in order to prevent the harvest of undersized perch, the minimum mesh size was increased in 2003 from 28 to $30 \mathrm{~mm}$ bar length. Psuty-Lipska et al. (2006) found that a $30 \mathrm{~mm}$ minimum mesh size should protect undersized perch. However, since the body shapes of these two fish are different, it is anticipated that the selectivity of the same gear will vary with regard to the two species. Perch become entangled easily in nets due to the spines in the dorsal fins and the shape of the operculum. A bimodal curve best illustrates the perch selectivity effect (Psuty-Lipska et al. 2006). In the case of cyprinids, entanglement in nets is of far less significance. According to the Baranov classification, these fish are usually caught in two ways: gilled (held by the mesh slipping behind the opercula) and wedged (held around the body at maximum girth) (Sparre et al. 1989). Thus, the $30 \mathrm{~mm}$ minimum mesh size may be ineffective at protecting undersized roach, and so the aim of the current investigation was to evaluate effectiveness of this regulation it terms of its protecting undersized roach.

Selectivity can be measured indirectly when comparing catches made with nets of different mesh size. Numerous models and methods have been developed to represent the selectivity of different gear and for estimating the parameters of appropriate selectivity models (e.g., Regier and Robson 1966, Hamley and Regier 1973, Holst and Moth-Poulsen 1995). Useful models estimate the parameters of pre-determined selectivity curves simultaneously across mesh size and size class from catch data

\footnotetext{
* Correspondence: Dr Iwona Psuty, Morski Instytut Rybacki w Gdyni, Kołłątaja 1, 81-332 Gdynia, Poland, phone: +48 587356218 , fax: +48 58 7356 110, e-mail: iwcia@mir.gdynia.pl
} 
(Kirkwood and Walker 1986, Wulff 1986). The SELECT method developed by Millar and Holst (1997), applied in the current paper, utilizes a general statistical model to estimate gillnet selection curves from comparative gillnet catch data. Log-linear modelling generalizes Holt's (1963) indirect estimation method by permitting several different selection curve models to be fitted to catch data of different mesh sizes. The objective of the present work was to model the size selectivity of the roach-perch gillnets currently used in the commercial fishery of the Szczecin Lagoon.

\section{MATERIALS AND METHODS}

Study area. The Szczecin Lagoon, a large $\left(687 \mathrm{~km}^{2}\right)$ shallow (average depth $3.8 \mathrm{~m}$ ) coastal flow reservoir, is a key element of the Oder (Odra) River estuary. The lagoon consists of two main parts - the Small Lagoon on the German side and the Great Lagoon located within Polish borders (Fig. 1). The Great Lagoon comprises about $60 \%$ of the entire lagoon area and the water volume. The time required for full water volume exchange (theoretical) is about two months. The Oder estuary is undergoing severe, progressive eutrophication due to heavy nutrient loads mainly from the Oder River. The nutrient concentration level exhibits high inter-annual variability over the long-

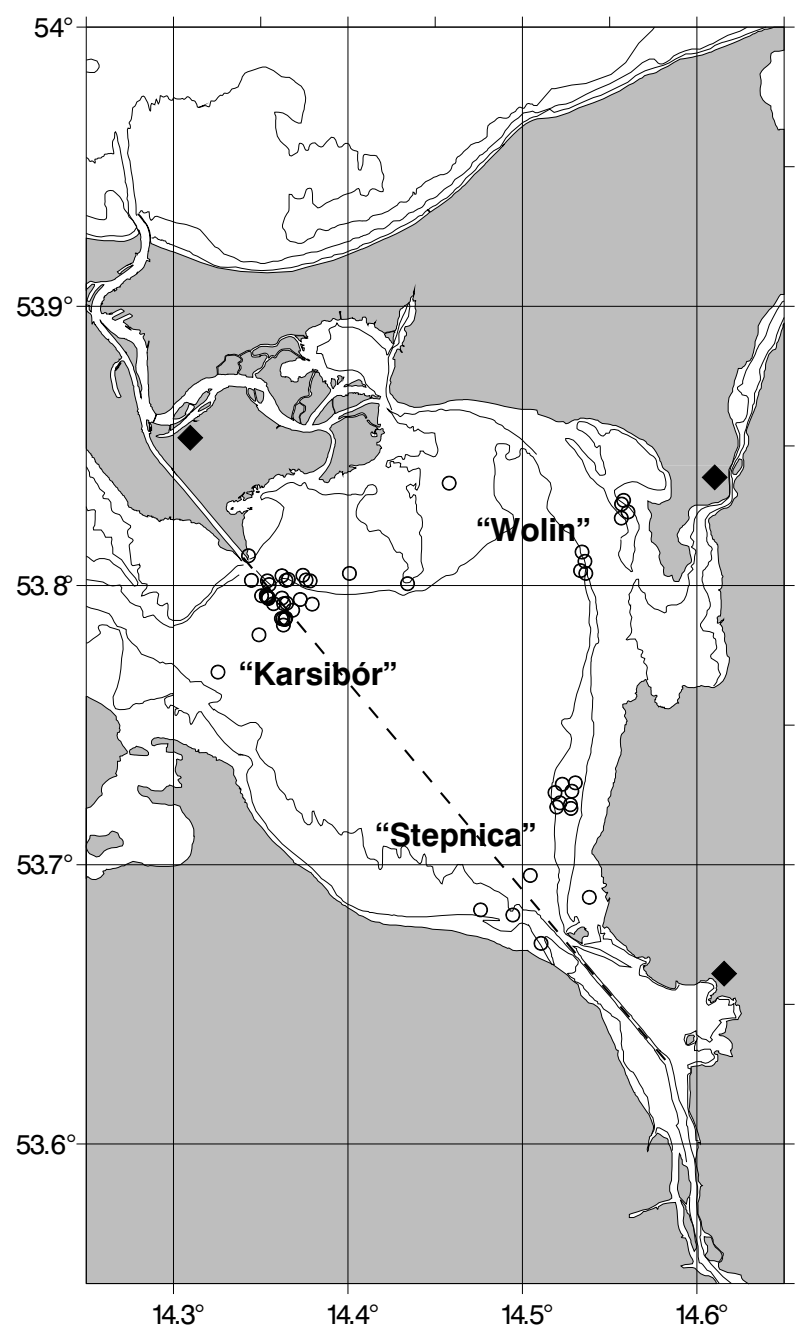

Fig. 1. Map of the Szczecin Lagoon showing the sampling sites term, and a decreasing trend has been noted in recent years. The poor water transparency in the lagoon results from high primary production and sediment resuspension (Schernewski and Wielgat 2001).

Fish sampling. Roach were caught with gang of four, anchored, perch, gillnets, set between June and November 2003. The nets were made of monofilament nylon netting material, made of single filaments, $0.20-\mathrm{mm}$ thick, and were dyed green. The gear height was 20 meshes, the length was 1900 meshes, and the length of the upper string was $44 \mathrm{~m}$, while the lower one was $52 \mathrm{~m}$ (Fig. 2). The hanging ratio was 0.38 and 0.45 on the upper- and lower strings, respectively. Each set consisted of 24 gillnets, and the nominal mesh sizes in one set were 25,26 , $28,30,32$, and $35 \mathrm{~mm}$ (four gillnets with one mesh size). In order to limit, as fully as possible, the impact of factors resulting from different locations, the fishing grounds were selected based on prior personal knowledge the local fishermen and each catch was supervised by inspectors from the local fisheries inspectorate. The depth of gillnet setting varied, depending on where the gear was deployed. Although they were, most often, placed at depths of 2-3 m, the gillnets located near the fairway were at depths of about 5-6 m. The time the nets were set, varied depending on weather conditions and water temperature, but generally this was done at $1300-1400 \mathrm{~h}$ or 1700-1800 $\mathrm{h}$ local time, and they were collected in the early morning hours. The presently reported study does not include an analysis of the way the different fish were caught in the mesh. All of the fish caught were sorted by species and then measured to the nearest $\mathrm{cm}$.

Selectivity modelling. The gillnet functions package for $R$ was used for selectivity modelling [GNU open source code by Millar (2003-2005); checked by the present authors on 05 June 2007]. This function fits relative retention curves to data from gillnet selectivity experiments using Generalized Linear Modelling. The retention curves tested were: normal-shaped with fixed spread, normal with spread proportional to mesh size, gamma-shaped, and log-normal-shaped (equations for the models are given with results in Table 1). Each selection curve was fitted twice, first under the assumption of equal efficiency (fishing power) of the gillnet and then again assuming fishing power to be proportional to mesh size. The plot of deviance residuals (McCullagh and Nelder 1989) was derived for goodness of final model fit estimation. The methodology and definition of parameters is given in Millar and Holst (1997).

\section{RESULTS}

Over 9000 roach specimens were caught throughout the study period. Generally, the greatest number of roach were caught by gillnets with a mesh size $26 \mathrm{~mm}$, while the smallest number were caught with nets of the largest mesh sizes, i.e., $35 \mathrm{~mm}$ (Table 2). The time period with the largest catch results was July and September. Roach length varied from 15 to $31 \mathrm{~cm}$ (Table 3). The height and, to a lesser extent, the shapes of the length distributions of 


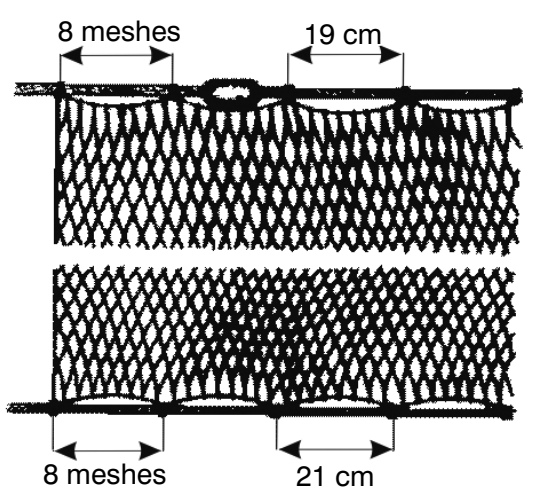

A

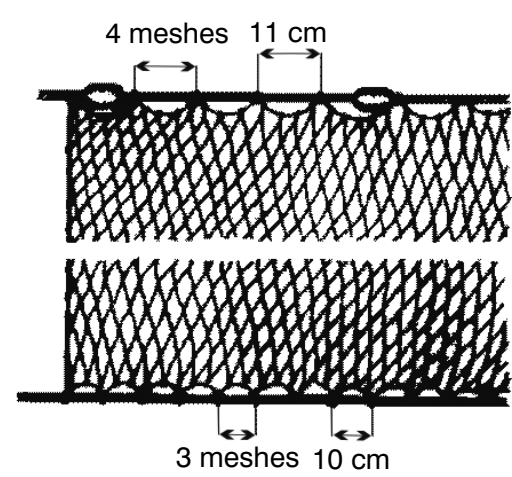

B

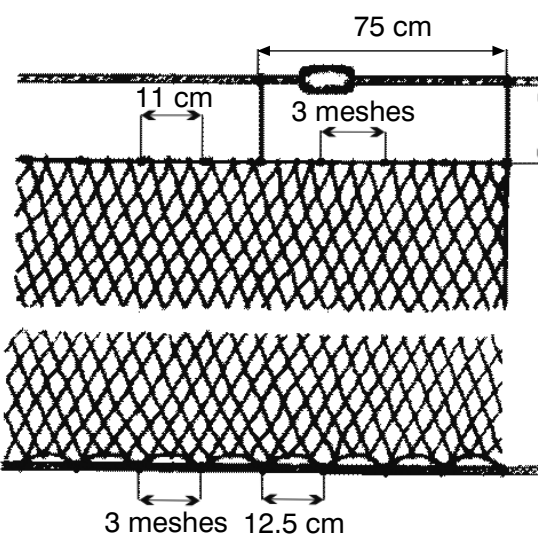

C

Fig. 2. Diagrams of perch gill nets used in experiments; mesh sizes: A, 25-26 mm; B, 28-30 mm; C, 32-35 mm

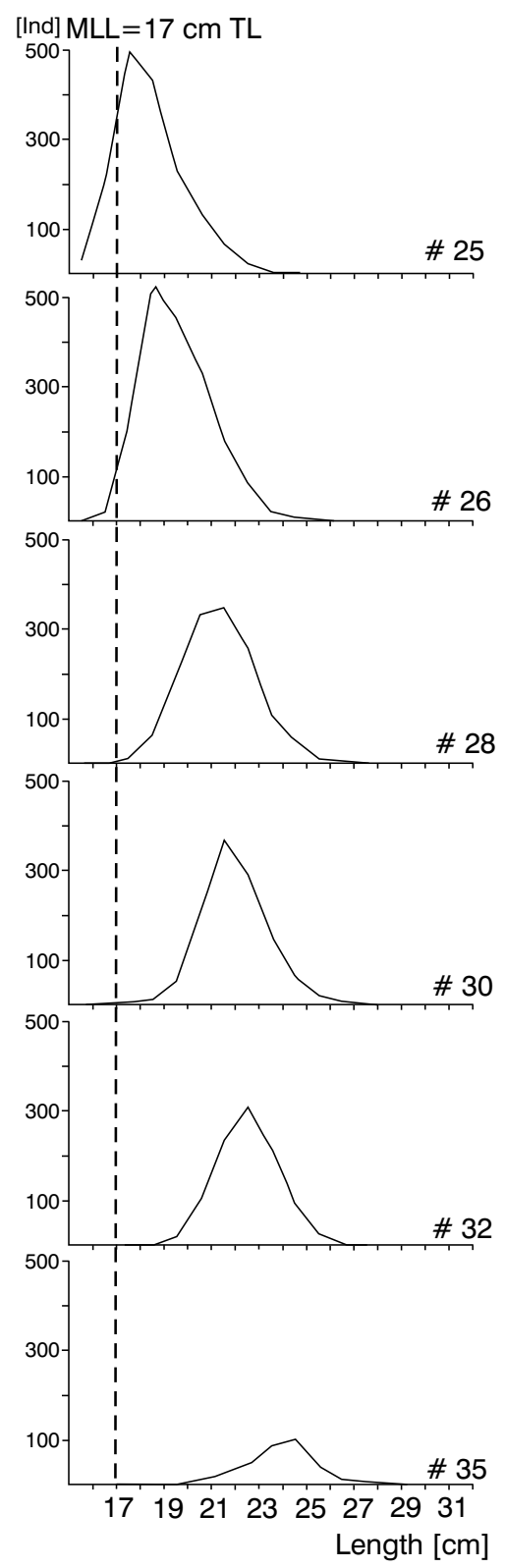

Fig. 3. Roach length frequency diagrams for gill nets with different mesh size roach specimens caught in particular gillnets varied between individual gillnets (Fig. 3). Roach under $17 \mathrm{~cm} \mathrm{TL}$ were rarely caught in meshes greater than $26 \mathrm{~mm}$ (Table 3 ).

The results of the relationship between roach and perch efficiency throughout the study period indicate that the proportion changed significantly (Table 3 ). In July and September, the numbers of roach significantly exceeded the numbers of perch caught at all mesh sizes, while in the rest of the year, but especially in late fall, the roach yield decreased and that of perch prevailed. These proportions also differed if the composition of catches in the nets with different mesh sizes were taken into consideration. The greatest differences between the proportions of caught perch and roach were observed in gillnets with mesh sizes of $32 \mathrm{~mm}$.

Selectivity model. For both normal selection curves (fixed and proportional spread) the model deviance was lower under the assumption of equal fishing power of different mesh sizes (Table 1). The model deviances from the gamma and lognormal selection curve models were not influenced by the fishing power assumption. Overall, the lognormal selection curve provided the best fit. A plot of deviance residuals shows general good fit (Fig. 4). Most of the residuals had a negative value (length class, mesh size), which meant that catches were actually higher than those forecast by the model for these variables. The modes and standard deviations of the retention curve for the smallest mesh $(25 \mathrm{~mm})$ did not differ significantly between models. The parameters for log-normal model assuming equal fishing power were 18.7 (mode of the curve) and 1.5 (standard deviation) (Fig. 5).

\section{DISCUSSION}

Roach plays an important role in the Szczecin Lagoon fishery. Roach are not targeted due to low profitability, but they often occur as bycatch. The size of roach landings in relation to total recorded catches has fluctuated from 20 to $50 \%$ over the last two decades (Fig. 6). Roach is the predominant planktivore, in the majority of shallow, eutrophic lakes in temperate Europe (Johansson and Persson 1986), and it is considered to have a significant impact on lower trophic levels and as such might be an important controlling 
Table 1

Log-linear fits to the roach data; the model deviance is the likelihood ratio goodness of fit statistics and it has 83 degrees of freedom for each of the models shown

\begin{tabular}{|c|c|c|c|c|c|}
\hline & \multirow[b]{2}{*}{ Selection curve equation } & \multicolumn{2}{|c|}{ Equal fishing powers } & \multicolumn{2}{|c|}{ Fishing power $\alpha$ mesh-size } \\
\hline & & Parameters & $\begin{array}{l}\text { Model } \\
\text { deviance }\end{array}$ & Parameters & $\begin{array}{l}\text { Model } \\
\text { deviance }\end{array}$ \\
\hline $\begin{array}{l}\text { Normal, } \\
\text { fixed } \\
\text { spread }\end{array}$ & $\exp \left(-\frac{\left(L-k \cdot m_{j}\right)^{2}}{2 \sigma^{2}}\right)$ & $\begin{array}{l}(k, \sigma)= \\
(0.746,1,751)\end{array}$ & 891.0 & $\begin{array}{l}(k, \sigma)= \\
(0.751,1.757)\end{array}$ & 899.4 \\
\hline $\begin{array}{l}\text { Normal, } \\
\text { spread } \\
\alpha, m_{j}\end{array}$ & $\exp \left(-\frac{\left(L-k_{1} \cdot m_{j}\right)^{2}}{2 k_{2} \cdot m_{j}^{2}}\right)$ & $\begin{array}{l}(k 1, k 2)= \\
(0.755,0.0028)\end{array}$ & 754.1 & $\begin{array}{l}(k 1, k 2)= \\
(0.759,0.0028)\end{array}$ & 754.8 \\
\hline $\begin{array}{l}\text { Gamma, } \\
\text { spread } \\
\alpha, m_{j}\end{array}$ & $\left(\frac{L}{(\alpha-1) \cdot k \cdot m_{j}}\right)^{\alpha-1} \exp \cdot\left(\alpha-1-\frac{L}{k \cdot m_{j}}\right)$ & $\begin{array}{l}(\alpha, \varkappa)= \\
(156.2,0.0048)\end{array}$ & 654.9 & $\begin{array}{l}(\alpha, x)= \\
(157.2,0.0048)\end{array}$ & 654.9 \\
\hline $\begin{array}{l}\text { Log- } \\
\text { normal, } \\
\text { spread } \\
\alpha, m_{j}\end{array}$ & $\frac{1}{L} \exp \left(\mu_{1}+\log \left(\frac{m_{j}}{m_{1}}\right)-\frac{\sigma^{2}}{2}-\frac{\left(\log (L)-\mu_{1}-\log \left(\frac{m_{j}}{m_{1}}\right)\right)}{2 \sigma^{2}}\right.$ & $\begin{array}{l}(\mu, \sigma)= \\
(2.935,0.0807)\end{array}$ & 622.9 & $\begin{array}{l}(\mu, \sigma)= \\
(2.942,0.0807)\end{array}$ & 622.9 \\
\hline
\end{tabular}

$L=$ abundance of length class; $m$, mesh size.

Table 2

Number of roach caught per set by mesh size and total catches; fishing area is indicated

\begin{tabular}{|c|c|c|c|c|c|c|c|c|c|}
\hline \multirow{2}{*}{$\begin{array}{l}\text { Time } \\
\text { period }\end{array}$} & \multirow{2}{*}{$\begin{array}{l}\text { Start date } \\
(2003)\end{array}$} & \multirow[b]{2}{*}{ Area } & \multicolumn{6}{|c|}{ Mesh size $[\mathrm{mm}]$} & \multirow{2}{*}{$\begin{array}{l}\text { Total catch } \\
\text { [fish No.] }\end{array}$} \\
\hline & & & 25 & 26 & 28 & 30 & 32 & 35 & \\
\hline \multirow{3}{*}{1} & 30 Jun & Stepnica & 300 & 366 & 304 & 126 & 206 & 47 & 1349 \\
\hline & $01 \mathrm{Jul}$ & Stepnica & 127 & 73 & 101 & 60 & 30 & 9 & 400 \\
\hline & 02 Jul & Stepnica & 117 & 129 & 100 & 100 & 69 & 16 & 531 \\
\hline \multirow{3}{*}{2} & $30 \mathrm{Jul}$ & Wolin & 11 & 29 & 10 & 1 & 3 & 0 & 54 \\
\hline & $31 \mathrm{Jul}$ & Wolin & 55 & 56 & 17 & 13 & 13 & 1 & 155 \\
\hline & 06 Aug & Wolin & 25 & 63 & 32 & 32 & 9 & 4 & 165 \\
\hline \multirow{3}{*}{3} & 04 Sep & Karsibor & 250 & 275 & 253 & 255 & 243 & 87 & 1363 \\
\hline & 06 Sep & Karsibor & 376 & 486 & 320 & 316 & 222 & 111 & 1831 \\
\hline & $08 \mathrm{Sep}$ & Karsibor & 265 & 318 & 218 & 232 & 202 & 39 & 1274 \\
\hline \multirow{2}{*}{4} & 17 Oct & Karsibor & 43 & 36 & 15 & 9 & 8 & 4 & 115 \\
\hline & $20 \mathrm{Oct}$ & Karsibor & 19 & 6 & 11 & 9 & 13 & 6 & 64 \\
\hline \multirow{3}{*}{5} & $13 \mathrm{Nov}$ & Karsibor & 34 & 13 & 4 & 8 & 4 & 1 & 64 \\
\hline & 17 Nov & Karsibor & 13 & 7 & 4 & 1 & 4 & 1 & 30 \\
\hline & & $\begin{array}{l}\text { Average } \\
\text { CPUE* }\end{array}$ & 31.4 & 35.7 & 26.7 & 22.3 & 19.7 & 6.3 & \\
\hline
\end{tabular}

* The average catch rates [ind.] per one gill net.

factor in the lake food web (Persson et al. 1991). The suc- a strong competitor with smaller-size classes of perch. cess of this species is related to: effective zooplanktivory in As roach are more effective predators on zooplankton than turbid waters (Lessmark 1983, Lammens et al. 1992); the perch, the degree of inter-specific competition between the capability of consuming plant material, including two species for this resource will limit the proportion of the cyanobacteria (Lessmark, 1983, Persson, 1983); and their perch population that reach the piscivorous stage (Persson high reproductive capacity and ability to spawn on multiple and Greenberg 1990).

substrates, even on bare sediments (Barthelmes 1983). Among different fish species, the morphological sites, Moreover, in the Szczecin Lagoon the predatory pressure where net enmeshing occurs, varies in position and proxon roach is significantly reduced due to the overfishing of imity (Reis and Pawson 1999). Percids have many such pike-perch (Draganik 2003). On the other hand, roach is sites (Psuty 1996), which means that there are various 
CPUE and general parameters of the length distributions of roach

Table 3

\begin{tabular}{|c|c|c|c|c|c|}
\hline \multirow{2}{*}{$\begin{array}{l}\text { Mesh size } \\
{[\mathrm{mm}]}\end{array}$} & \multirow{2}{*}{$\begin{array}{l}\% \text { under } \\
\text { Minimum } \\
\text { Landing } \\
\text { Length }\end{array}$} & \multicolumn{4}{|c|}{ Length distribution $[\mathrm{cm}]$} \\
\hline & & Range & Mean & $s$ & Modal \\
\hline 25 & 14.8 & $15-25$ & 17.8 & 1.5 & 17 \\
\hline 26 & 1.2 & $15-25$ & 19.0 & 1.6 & 18 \\
\hline 28 & 0.1 & $15-26$ & 20.8 & 1.7 & 21 \\
\hline 30 & 0.0 & $17-27$ & 21.5 & 1.9 & 21 \\
\hline 32 & 0.0 & $17-30$ & 22.0 & 1.9 & 22 \\
\hline 35 & 0.0 & $17-31$ & 23.3 & 2.0 & 24 \\
\hline
\end{tabular}

The roach abundance ratio (roach/perch) in the gill net catches during the study season

Table 4

\begin{tabular}{lccccccc}
\hline \multirow{2}{*}{$\begin{array}{l}\text { Time } \\
\text { period }\end{array}$} & 25 & 26 & 28 & 30 & 32 & 35 & $\begin{array}{c}\text { Average } \\
\text { for all } \\
\text { mesh } \\
\text { sizes }\end{array}$ \\
\hline 1 & 1.44 & 3.21 & 4.35 & 7.15 & 11.73 & 7.2 & 3.05 \\
2 & 0.19 & 0.17 & 0.88 & 1.05 & 1.32 & 0.38 & 0.30 \\
3 & 1.53 & 1.76 & 3.61 & 4.84 & 6.54 & 2.32 & 2.59 \\
4 & 0.13 & 0.16 & 0.15 & 0.12 & 0.17 & 0.12 & 0.14 \\
5 & 0.19 & 0.06 & 0.36 & 0.29 & 0.47 & 0.17 & 0.19 \\
\hline
\end{tabular}

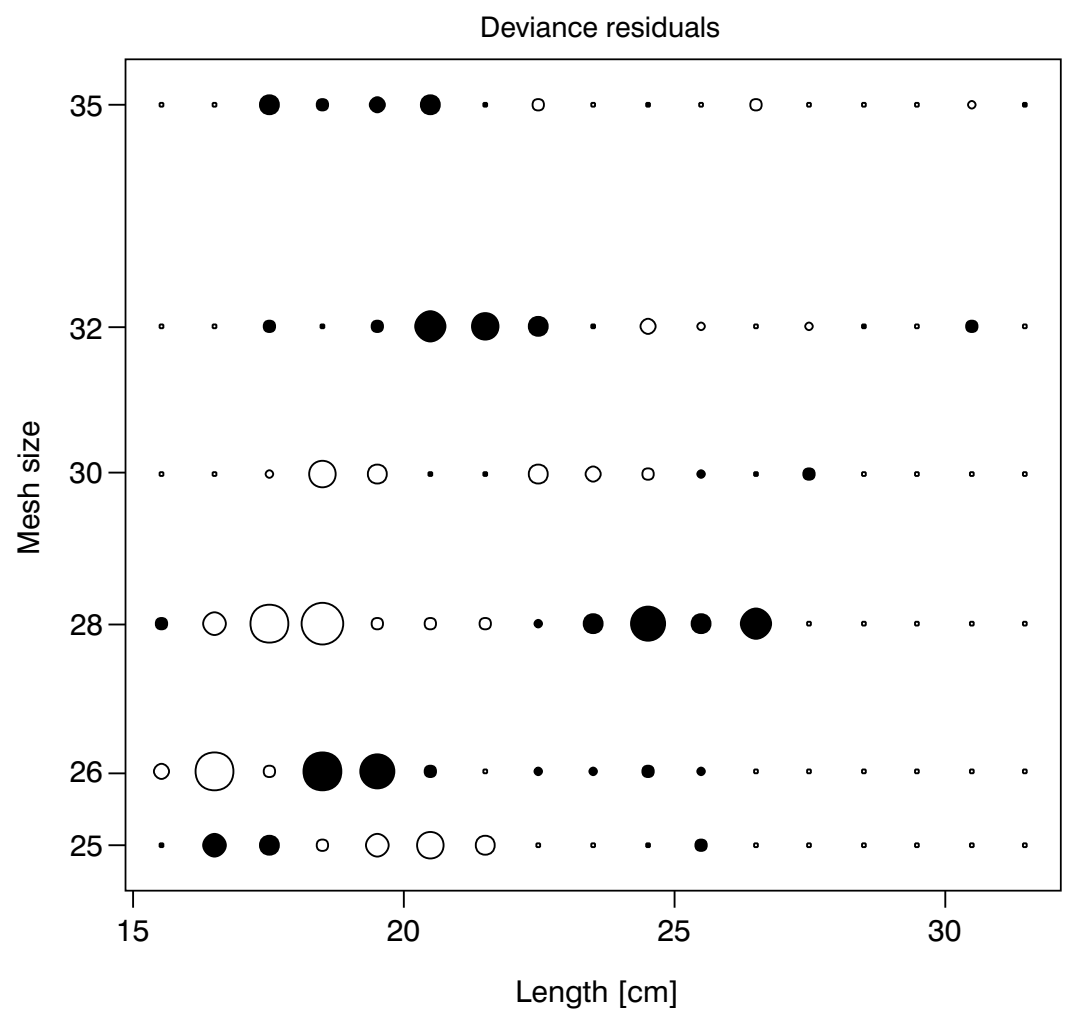

Fig. 4. Plot of deviance residuals for log-normal retention curves; the size of the circle is proportional to the size of residuals; $\bigcirc$ positive value of residuals negative value of residuals 


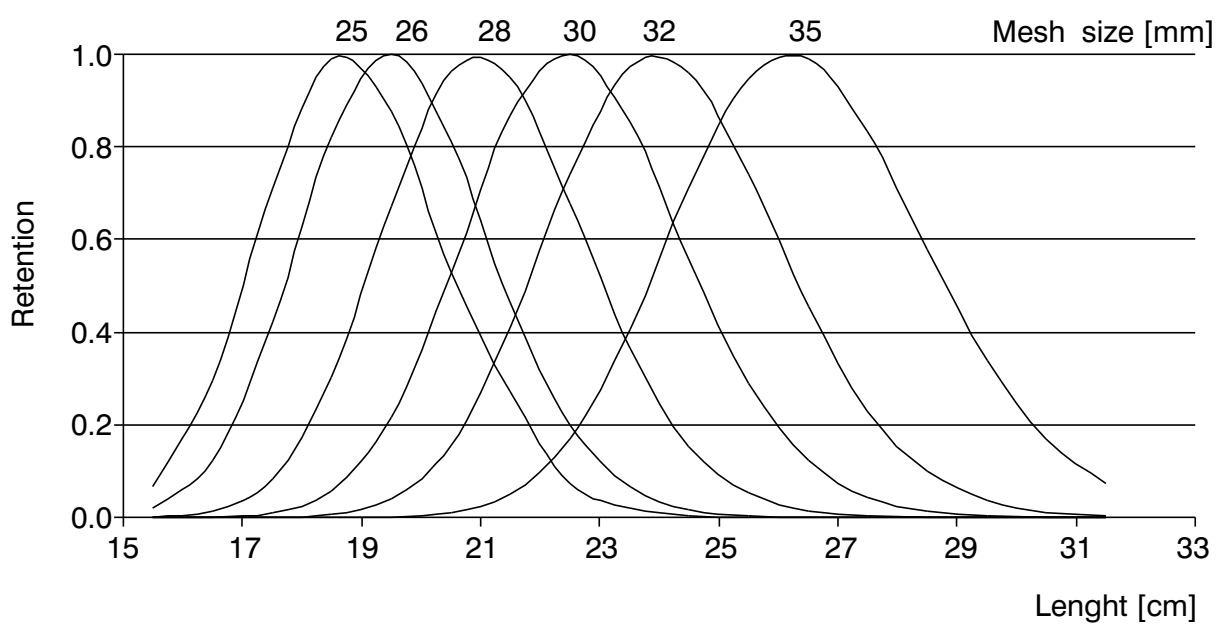

Fig. 5. Log-normal retention curves for roach

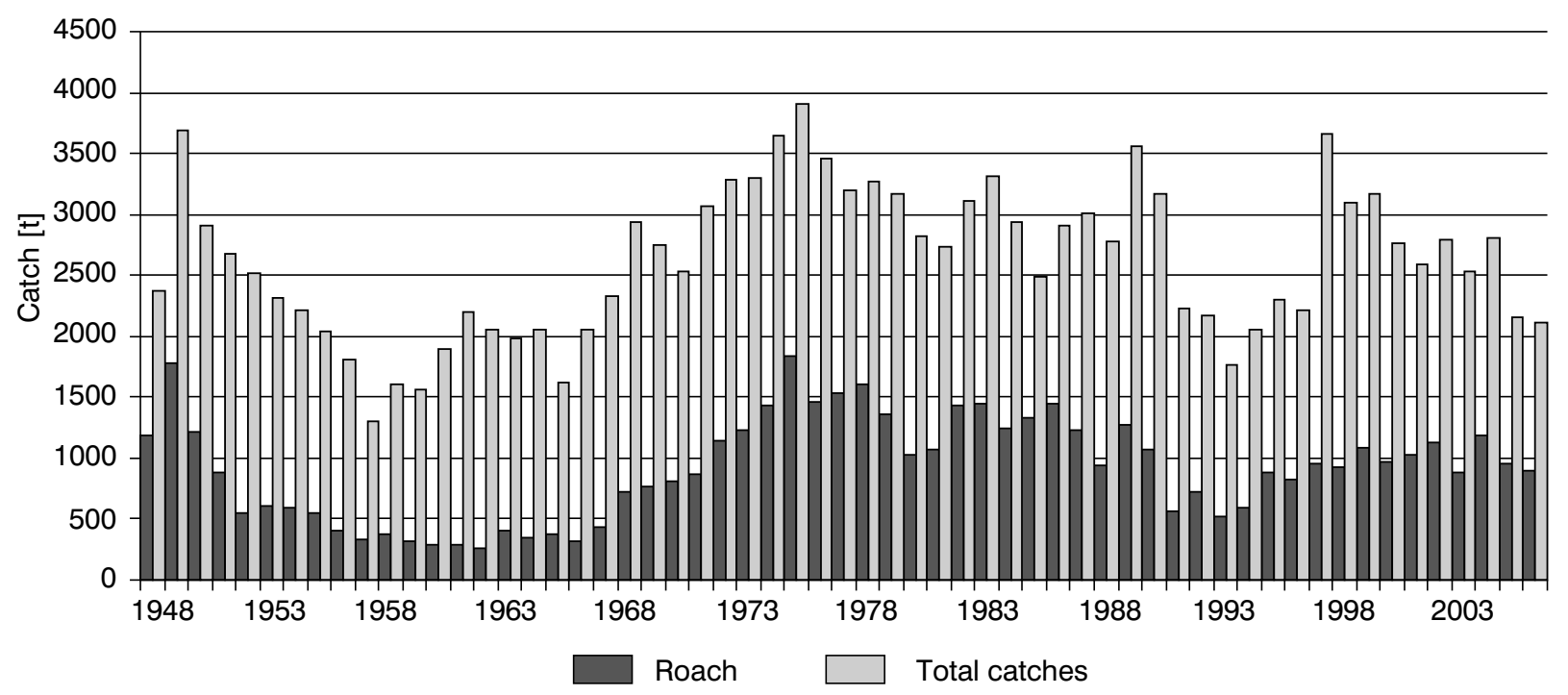

Fig. 6. The roach catches from the Polish part of the Szczecin Lagoon

ways these fish become enmeshed in the nets. The bi-nor- a compromise between the relative effectiveness and the mal selection curve likely reflects the combined effects of length structure of the perch caught. With regard to roach several capture modes (Holt 1963, Hamley and Regier MLL, none of the mesh sizes were a limiting factor in the 1973, Hamley 1975). In cyprinid or clupeid species the number of sites where the fish can become enmeshed are fewer than in percids (Psuty and Borowski 1997, Reis and Pawson 1999). Thus, a unimodal selection curve would be efficient to describe the selectivity model (McCombie and Berst 1969, Hamley and Regier 1973), as was determined in the current study.

Differences in the body builds of cyprinid and percid species also means that gear of a particular size is selective for various length classes of these fish. In nets with the smallest mesh size $(25 \mathrm{~mm})$, nearly $30 \%$ of the catches were comprised of undersized fish (MLL $=17 \mathrm{~cm})$. This eliminates gear of this mesh size as potential fishing gear in the Szczecin Lagoon (Psuty-Lipska et al. 2006). Nets with a mesh size of $26 \mathrm{~mm}$, are the most efficient with respect to roach; however, they still do not prevent catching undersized perch. The next mesh size $(28 \mathrm{~mm})$ is deployment of this gear. This suggests that the current mesh size regulations, originally aimed at preventing the harvest of undersized perch, should also be effective for roach. In the resource protection model discussed, in which perch selectivity was dependent on gear mesh size, the varied selectivity results with regard to the roach that co-occurred in the catches do not have any practical significance. This situation might change if, despite current regulations, perch resources in the Szczecin Lagoon decrease to a level at which its exploitation becomes ineffective. In this event, the minimum mesh size, which is larger than necessary for roach protection, might become a source of conflict between management and fishers.

Reasonable multispecies management is usually difficult to implement in real ecosystems. Fisheries management should consider not only achieving objectives that relate to the well-being of commercially important har- 
vested species but, more broadly, to ecosystem-orientated objectives as well (Sainsbury et al. 2000). These include bycatch estimation and protection by evaluating the performance of the adaptive management system (Walters and Hilborn 1976). In the case of perch-roach gillnet fishery in the Szczecin Lagoon, adaptive management should be based on monitoring data including stock assessments, net catchability, and potential changes in selectivity caused by new constructions as well as trends in market demands.

\section{ACKNOWLEDGEMENTS}

The authors are greatly indebted to the fishermen operating in the Szczecin Lagoon. Particularly, Mr. K. Nowicki, who cooperated to make available materials for the study. The authors also thank Mr. E. Boberski from the the Sea Fisheries Institute Station at Świnoujście, who assisted over the years of the project in the field work.

\section{REFERENCES}

Barthelmes D. 1983. Effects of eutrophication and fisheries management on fish faunas of cyprinid lakes. Roczniki Nauk Rolniczych $\mathbf{H} 3$ (100): 31-44.

Draganik B. 2003. The exploitation of pikeperch in the Polish Part of the Szczecin Lagoon. Acta Scientarum Polonorum, Piscaria 2: 55-70.

Hamley J.M. 1975. Review of gillnet selectivity. Journal of the Fisheries Research Board of Canada 32: 1943-1969.

Hamley J.M., Regier H.A. 1973. Direct estimates of gillnet selectivity to walleye (Stizostedion vitreum vitreum). Journal of the Fisheries Research Board of Canada 30: 817-830.

Holst R., Moth-Poulsen T. 1995. Numerical recipes and statistical methods for gillnet selectivity. ICES Conference Meeting 1995 B/18.

Holt S.J. 1963. A method for determining gear selectivity and its application. ICNAF Special Publication 5: 106-115.

Johansson L., Persson L. 1986. The fish community of temperate eutrophic lakes. Pp. 237-266. In: Riemann B., Søndergaard M. (eds.) Carbon Dynamics of Eutrophic, Temperate Lakes: the Structure and Function of the Pelagic Environment. Elsevier, Amsterdam.

Kirkwood G.P., Walker T.I. 1986. Gill net mesh selectivities for gummy shark, Mustelus antarcticus Günther, taken in south-eastern Australian waters. Australian Journal of Marine and Freshwater Research 37: 689-697.

Lammens E.H.R.R., Frank-Landman A., McGillavry P.J., Vlink B. 1992. The role of predation and competition in determining the distribution of common bream, roach and white bream in Dutch eutrophic lakes. Environmental Biology of Fishes 33: 195-205.

Lessmark O. 1983. Competition between perch (Perca fluviatilis L.) and roach (Rutilus rutilus L.) in south Swedish lakes. PhD thesis, Institute of Limnology, University of Lund, Sweden.

McCombie A.M., Berst A.H. 1969. Some effects of shape and structure of fish on selectivity of gillnets. Journal of the Fisheries Research Board of Canada 26: 2681-2689.
McCullagh P., Nelder J.A. 1989. Generalized linear models. 2nd edn. Chapman and Hall, London.

Millar R.B. 2003-2005. The gillnetfunctions package for R. http://www.stat.auckland.ac.nz/ millar/selectware/R/gillnets/.

Millar R.B., Holst R. 1997. Estimation of gillnet and hook selectivity using log-linear models. ICES Journal of Marine Science 54: 471-477.

Persson L. 1983. Effects of intra and interspesific competition on dynamics and size structure in a roach (Rutilus rutilus) and a perch (Perca fluviatilis) population. Oikos 41: $126-132$

Persson L., Diehl S., Johansson L., Andersson G., Hamrin S.F. 1991. Shifts in fish communities along the productivity gradient of temperate lakes - patterns and the importance of size-structured interactions. Journal of Fish Biology 38: 281-293.

Persson L., Greenberg L.A. 1990. Juvenile competitive bottlenecks: the perch (Perca fluviatilis) and roach (Rutilus rutilus) interaction. Ecology 71 : 44-56.

Psuty I. 1996. Selectivity in gill-net fishery for pikeperch in the Polish part of the Vistula Lagoon. Bulletin of the Sea Fisheries Institute 3 (139): 13-28.

Psuty I., Borowski B. 1997. The selectivity of gill nets to bream (Abramis brama L.) fished in the Polish part of the Vistula Lagoon. Fisheries Research 32: 249-261.

Psuty-Lipska I., Madsen N., Draganik B., Blady W. 2006. Gill net selectivity for perch (Perca fluviatilis) in the Szczecin Lagoon, Poland. Fisheries Research 80: 339-344.

Regier H.A., Robson D.S. 1966. Selectivity of gillnets, especially to lake whitefish. Journal of the Fisheries Research Board of Canada 23: 423-454.

Reis E.G., Pawson M.G. 1999. Fish morphology and estimating selectivity by gillnets. Fisheries Research 39: 263-273.

Sainsbury K.J., Punt A.E., Smith A.D.M. 2000. Design of operational management strategies for achieving fishery ecosystem objectives. ICES Journal of Marine Science 57: 731-741.

Schernewski G., Wielgat M. 2001. Eutrophication of the shallow Szczecin Lagoon (Baltic Sea): modelling, management and the impact of weather. Pp. 87-98. In: Brebbia C.A. (ed.) Coastal engineering. Computer Modelling of seas and coastal regions. Witpress, Southampton.

Sparre P., Ursin E., Venema S.C. 1989. Introduction to tropical fish stock assessment. Part 1. FAO Fisheries Technical Paper 306/1.

Walters C.J., Hilborn R. 1976. Adaptive control of fishing systems. Journal of the Fisheries Research Board of Canada 33: 145-159.

Wulff A. 1986. Mathematical model for selectivity of gill nets. Archiv für Fischereiwissenschaft 37: 101-106.

Received: 23 March 2007

Accepted: 11 June 2007

Published electronically: 15 July 2007 